\title{
The choice explosion: human lives, human genes, human numbers
}

\author{
WALTER TRUETT ANDERSON \\ President's Office, World Academy \\ of Art and Science \\ 760 Market Street, \\ San Francisco CA 94102 USA \\ E-mail: waltt@well.com
}

Received February 20, 2008
In a few hundred years, when the history of our time will be written from a long-term perspective, it is likely that the most important event historians will see is not technology, not the Internet, not e-commerce. It is an unprecedented change in the human condition. For the first time - literally - substantial and rapidly growing numbers of people have choices. For the first time they will have to manage themselves. And society is totally unprepared for it.

Peter F. Drucker

$I^{2}$

have added »The Choice Explosion« in front of the title I originally proposed to the organizers of this conference because choice - actually the proliferation of choice that Peter Drucker pointed out — is the reason we are here.

Today, people all over the world are swimming (and sometimes drowning) in options, enabled (and often forced) to make decisions about things their parents - and certainly their grandparents - had no idea they could make decisions about: where to live, what to do for a living, how many children to have, what religion (or non-religion) to follow This proliferation of choice touches human life at all levels - individuals, families, communities, organizations, national governments. Even global civilization as a whole is faced with the new and disturbing need to make choices about the very future of the planet's climate.

There are many reasons for this; I am inclined to identify scientific/technological progress and globalization - which is in part the result of it - as the major forces that are carrying us into this astonishingly choice-filled century, this time in which we have infinitely more choices but do not seem to have a choice about whether we have more choices. Today we all live in the whole world, and we all know - in different degrees of course - that there are many ways of living, many ideas and opinions about every subject. We are, as psychologist Kenneth Gergen puts it, »saturated, « in a way that people have never been before, with messages that flow into our minds from the diverse communications media and the experiences of life in multicultural environments (1). We receive diverse and often contradictory statements about what is right and true, even about what we are. We know, too, that this new world is not simply something that has arrived, but something that is continually arriving, bringing new surprises, good and bad, and more things to make choices about. 
And among the stunningly wide range of things that people now make choices about are matters of birth and death: whether to fertilize an egg, or terminate a pregnancy; whether to extend a human life - perhaps all human lives, far beyond anything previously known, as some are now seriously proposing - or bring one to a painless conclusion. I want to point out that it is not only the people who decide to use new reproductive choices such as in vitro fertilization who are making choices, but also the people who decide not to use them. This is the larger landscape in which we live now, and which we are gathered here to inquire into and deliberate about. Before I proceed with what I want to say about this, let me come down from this level of high generalization and give a couple of specific examples:

- Example One: My local newspaper, the San Francisco Chronicle, reported that a child had been born, conceived by in vitro fertilization. This in itself was not news; it has been almost 30 years since the first child, Louise Brown, was conceived as a »test tube baby." The news was that the embryo had been frozen for 13 years (2). I find this interesting not only because it further complicates the discussion about the beginning of human life - when did this child's life begin? - but also because behind that child's birth lay a long train of other choices: the couples' choices of one another as parental partners; their choice to resort to IVF; their choice to have the embryos frozen; the choice of this particular embryo out of the many they might have selected as the one to thaw out, implant in the prospective mother, and bring to life.

- Example Two: A book about the rapidly-expanding business of in vitro fertilization describes how it has become international. The author gives an example of a company called Global ART (ART stands for Assisted Reproductive Technologies): »Circumventing those aspects of reproductive technology (like egg freezing) that do not work reliably yet, and taking advantage of those (like sperm freezing) that do, Global ART rather ingeniously conducts transactions by shipping a prospective father's frozen sperm to the lab in Bucharest, where it is thawed and used to fertilize the eggs of a Romanian donor. The resulting human embryos - half American, half Romanian - are then frozen and shipped back to the United States, where they are thawed and transferred into the prospective American mother, all for much, much cheaper than can be done with a U.S. donor, in part because Romanian egg donors are paid so much less than U.S. donors are. And you don't even need a passport for the embryos.«(3)

\section{The evolution of reproduction}

The two examples I have given may seem a bit bizarre, but they are by no means unusual. In vitro fertilization has come a long way since the birth of Louise Brown. There are now millions of people in the world who were conceived in a Petri dish. In Finland, approximately four percent of the population are the products of IVF.
The general pattern has been that reproductive innovations are opposed at first and then more widely accepted. The fears and uncertainties are gradually overwhelmed by the powerful urge to procreate.

Consider the case of artificial insemination. Initially developed mainly for animal breeding, it was being used by some doctors (nobody knows exact numbers) as early as the mid-19th century. The first such treatments used the husband's sperm and were meant to treat female infertility, such as cases in which malformation of the cervix prevented entry of sperm into the uterus. Later came artificial insemination by donor (AID), which was essentially a treatment for male infertility - cases in which, because of low sperm count or other reasons, the husband could not father a child.

AID has come into extremely wide acceptance in the West now, and the social practices surrounding it have gone through an interesting evolution that can only be understood by taking a brief look at the history of eugenics.

Eugenics, as I'm sure most of you know, was the brainchild of Francis Galton, a cousin of Charles Darwin. Galton selected the word from a Greek root meaning »well born, « and went public with his proposal to move evolution from theory to practice through a program to improve the quality of the human species. His ideas about what constituted genetic superiority were rather primitive - he more or less equated it to social class - and his ideas about how to achieve a eugenic society evolved not toward greater individual choice, but rather toward the belief that reproduction should be directed by the state, which would determine which people were the most fit to reproduce and which people should be prevented from passing their inferior genes on to future generations (4). Eugenics enjoyed considerable popularity among British intellectuals in the early decades of the $20^{\text {th }}$ century, but never came close to being adopted as a governmental program; that came later, in Hitler's Germany.

However, eugenics became highly influential in the United States - more so than it had been in Britain - and left its mark on restrictive federal immigration laws that reflected the fears of many Americans (most of who were then of Western and Northern European descent) that the national gene pool was being corrupted by newcomers from places such as Italy and Eastern Europe who were genetically predisposed toward criminal tendencies and mental deficiencies (5). Eugenic principles were also the rationale for many state laws that legalized the sterilization of mental patients and criminals, and laws prohibiting interracial marriage.

Those sterilization and marriage laws have been repealed now, but the basic spirit of eugenics - the belief that qualities contributing to superior human health and success are genetically inherited - is still very much with us.

It was with us in the early stages of artificial insemination by donor, when it was primarily regarded as a treatment for infertility and supervised by a doctor, when the sperm donor was likely to be a male medical student, when the aim was to create offspring that would not only 
be satisfactory to the parents but also »as near as humanly perfect as our scientific knowledge can produce « and where the couple should be only those whose parenthood would be »apt to improve society« (6).

Despite the high intentions of the early promoters of artificial insemination by donor, it ran into some serious legal obstacles in the early $20^{\text {th }}$ century. In 1921 , the husband in a divorce case in Canada argued that his wife, who had conceived a child through artificial insemination by donor against his wishes, was guilty of adultery. The Canadian court did not give a clear ruling on that issue, but a few decades later a court in Illinois did. Its decision said: »Artificial insemination (by donor), with or without the consent of the husband, is contrary to public policy and good morals, and constitutes adultery on the part of the mother. A child so conceived is not a child born in wedlock and is therefore illegitimate« (7).

Since then, in a rather short period of time, the practice has gained legal acceptance and public respectability in the United States and most Western countries, and it has also undergone a remarkable transformation, from the status of medical therapy to that of a highly successful business. Most sperm banks are now privately owned and operated and, although the eugenic overtones are still present there is a strong note of consumerism - and consumer choice. One report notes that a large sperm bank near Boston contains some 165,000 vials of sperm, and »consumers can peruse donor catalogues listing the race, ethnicity, height, weight, hair color, hair texture, skin tone, facial structure, IQ, hobbies, talents, and interests of the men whose sperm is for sale $\ll(8)$.

\section{Facts and questions about in vitro fertilization}

In vitro fertilization (IVF) has emerged more recently, grown into another sizeable industry. It has enabled many couples to become happy parents and brought many healthy children into the world. But although it is often accepted by ethicists and religious leaders where artificial insemination by donor is not - at least in the cases where the married couple are the biological parents and no egg donation is involved - it has raised many questions and concerns. Here I will touch briefly on only a few of those:

- One is the problem of what to do with embryos not used in conception. At the present time there are about one-half million frozen embryos in storage in the U.S. Parents must make regular payments to keep them in storage or make the difficult decision to have them destroyed. One solution is to locate a couple who is anxious to »adopt « an embryo, and there is a company that is in the business of doing this. Another is to use the embryos for stem cell research, which has led to huge political, scientific and ethical controversies over the very subject we are here to discuss today.

- Linked to the increase in IVF in developed countries is a remarkable change in the age at which women become mothers - a significant decline in the birthrates among women in their 20 s and corresponding increases in the numbers of women who become mothers in their $30 \mathrm{~s}$, 40 s, or even 50 s.

- Another statistic is the rise of multiple births. Twins, once a rarity, are becoming increasingly common not only because of IVF, but because older women are more likely to conceive twins.

- Although ethicists pay a good deal of attention to futuristic forecasts of conceiving "perfect « or at least significantly enhanced babies through genetic manipulation, there have been no recorded cases of such enhancements thus far and much evidence of the reverse - that is, children born prematurely, with low birth weight and other serious medical deficiencies.

I'm sure we will hear more about these matters in the course of the day, and before I conclude my remarks I would like to change the subject from birth to death from the beginning of life to the end of it. Because even though this is not part of the stated business of this conference, it is part of the world we live in now, the world of proliferating choice.

\section{The death of death?}

The growing practice of organ transplantation is yet another way in which science has changed the rules of life, brought new choices and uncertainties into the world, and also created new connections among human beings. Because, just as a woman may conceive a child whose biological father is a man she has never met, the hearts of people alive today may end up beating in the bodies of others they have never seen. Organ transplantation also creates new areas of conflict and controversy, because of the intense need to achieve agreement on precisely when a human being - say an accident victim lying in a hospital - may be determined medically and legally dead, and his or her body suitable for being harvested to obtain replacement organs and tissues for others. There are cases when practitioners have been suspected or accused of hastening the death so that the harvesting may get underway.

These cases are similar to the conflicts and controversies around the care of the terminally ill, when a life may be prolonged by heroic measures or brought to a conclusion. More choices, and difficult ones.

And a whole new area of conflict and controversy and ethical concern, and personal choice beyond anything the world has ever seen - is now coming into public awareness with the emerging field of life extension. The ancient quest for immortality is now being led not by sorcerers but by scientists and technology enthusiasts.

A couple of years ago I participated in a small conference with the well-known inventor and futurist Ray Kurzweil, who gave us all a copy of one of his books, which was what you might call a self-help work about how to live long enough to live forever. Its thesis is that if 
people now in middle age can take care of themselves well enough to live to be 120 or so — pretty much the outer limit or human life expectancy today — they will reach the point at which science will have conquered all diseases, and aging itself, and made it possible to live forever (9).

People will then die only by accident or choice - by accident is meant something irreparable such as getting blown up by an atomic bomb; by choice, presumably just because they have seen enough.

More recently, in fact earlier this month, Aubrey de Grey from England has brought forth a new book along similar lines: titled Ending Aging, it expounds on what de Grey calls the emerging science of Strategies for Engineered Negligible Senescence - SENS, for short. The use of the term »engineered « expresses de Grey's viewpoint that the body is a machine, and can be kept in good working order in more or less the same way one might preserve a vintage car (10).

Now, I have to confess that I am having a lot of trouble with this line of thinking. I am generally well-disposed toward science and technology and not in the habit of raining on people's parades. But I am troubled by the scarcity of ethical considerations in most of the live-longer and live-forever rhetoric that I have been hearing in recent years. The ethical sensitivity I believe we need to bring to bear on this is not so much the sort we usually think of in consideration of medical and biological issues, but rather a greater concern for the equity and ecology aspects.

Equity means fair distribution of goods and services. Equity issues are usually political, or potentially so. The American political scientist Harold Lasswell defined all politics as essentially a matter of who gets what, when and how. Certainly life expectancy is not being equally distributed in today's world. I just consulted Google on this and found a list of life expectancy by countries around the world: There are 15 countries at the top of the list in which average life expectancy (male and female) is over 80 . There are 19 countries in which it is under 50 . Swaziland is at the bottom, with average expectancy of $39.6-$ less than half that of those at the top (11). And there is reason to expect that the gap is growing, with more people living longer in the countries most of us live in, and dying sooner in countries of sub-Saharan Africa. As the old saying has it, the rich gets richer and the poor gets poorer. Now it's the rich live longer and the poor die sooner - and more miserably.

The equity issue does get some attention; I occasionally read speculations that the human species is in danger of dividing into two species - one long-lived and healthy, the other short-lived and sickly. There is practically no consideration whatever being given to the ecological implications of increases in life expectancy - especially dramatic increases of the sort now being confidently predicted - and there should be. Forty years ago, when Paul Ehrlich's book The Population Bomb (12) was published, we learned to think about the ecological impacts of rising human birthrates. (As it turned out, much to everybody's surprise (including Ehrlich's), birth rates began to decline in much of the world and today national governments are trying madly to get their citizens to have more children.) Today, if the projections of people such as Kurzweil and de Grey are to be taken seriously, we need to think about the possible ecological impacts of falling death rates. I don't see any immediate threat of global overcrowding from that direction, but it is never to early to think about ecological impacts when you are talking about major changes in the world.

\section{The future of life: three scenarios and one prediction}

Now, I understand that the purpose of this conference is to focus on specific scientific, and religious concerns about the beginning of human life. My remarks here have been merely an attempt to sketch the outlines of the larger context, the changing social and political landscape within which people will engage those questions. Mostly I have drawn from recent history, going back into the $19^{\text {th }}$ century, and from current news. Here, in closing, I want to speculate briefly on where we go from here. I'll do this in the form of three scenarios and one prediction.

Scenarios are not meant to be statements of what is going to happen. They are plausible stories of what might happen that people construct for the purpose of testing strategies and stretching their imaginations. Predictions are statements of what is going to happen. I'll call the scenarios The Age of Intentionality, Back to Nature, and the War of the Silos.

- The Age of Intentionality: »Intentionality « is an English word that describes things done on purpose, deliberate, resulting from conscious choice. This scenario describes a world in which people generally accept scientific and technological innovations of all kinds, and regard it as natural that they should have many options and make many choices about such things as reproduction. Education, governance, social rituals, laws and customs enfold these into the fabric of their individual and social lives.

- Back to Nature: The early $21^{\text {st }}$ century brings a wave of intellectual, religious and ecological reactions against all the modifications of what were once accepted as the normal ways of having children, dealing with age and death, growing food. Disparate groups - environmentalists, Luddites, people of many different religious and spiritual persuasions, all express in different ways a yearning for a way of life closer to unspoiled nature. This takes many forms, from eco-sabotage to governmental policies restricting technological experimentation to an growing interest in such practices as organic farming and natural childbirth.

- War of the Silos. The word »silo, « describing the strictures that hold agricultural products such as corn, has come into common usage in English to describe the social or political structures within 
which people hunker down in the company of those who hold the same allegiances and belief. This is what is happening now to a considerable degree and this scenario describes a world in which countries withdraw from global engagement. Some groups seek out spiritual cults and nature-based communities while others embrace the advances of science and technology. The prevailing action is the choice of fewer choices - locating a community, either based in a geographic region or floating through the successors of the internet and the web - where people can interact primarily with people who think as they do and avoid the stresses of cultural saturation.

There are movements and tendencies in each of these directions. Personally I am inclined to think we are living in the world of silos: many people, groups and societies are embracing scientific/technological advances and cultural change, while others throw up the barricades and seek a future based on the past. T and, although most serious futurists believe that one should not choose favorites when constructing a set of scenarios, I will break the rules here and say it seems to me we are well into the war of silos.

I said I would make a prediction. It's a fairly simple one. We are living in a time of unprecedented scientific and technological change, and I believe it has scarcely begun. We will see in the decades ahead an acceleration of innovation based on the convergence of rapid advances in such fields as information/communications technology, nanotechnology, genetics, and the science of materials. We will see inventions that can create life, and help restore the health of the planet, and we will see inventions that can destroy life in ways and on scales previously unknown. We will see further expansions of things that people can and must make choices about. That is the paradox of choice: in today's world, we don't seem to have any choice about whether we have more choices.
This is in many ways an explosive situation, and there is enormous need for learning, educating, and dialogue about the sort of issues we are discussing here today.

Dialogue is different from debate, even from what we usually call discussion. It recognizes, and even celebrates, differences of opinion, but a gathering based on the principle of dialogue is one in which people listen as well as speak, and look for areas of agreement as well as points of difference. It's an old invention, probably invented and reinvented for thousands of years around countless campfires, now being invented again in universities and think tanks and practiced in organizations and community meetings. It is the way out of the silos. It's a rather simple invention, but in the long run I think it may be the one that saves us.

\section{REFERENCES}

1. KENNETH J, GERGEN 1990 The Saturated Self: Dilemmas of Identity in Contemporary Life. Basic Books, p 69

2. JULIE FOSTER 2007 »Baby-making these days is swaddled in complexity«. San Francisco Chronicle, April 13.

3. LIZA MUNDY 2007 Everything Conceivable: How Assisted Reproduction is Changing Men, Women, and the World. Knopf, p 6

4. DANIEL J. KEVLES 1984 »Annals of Eugenics, « Part I. The New Yorker, Oct., 8, p 51

5. DANIEL J. KEVLES 1984 »Annals of Eugenics, « Part I. The New Yorker, Oct., 8, p 102

6. CYNTHIA R. DANIELS 2004 »Procreative compounds: popular eugenics, artificial insemination and the rise of the American sperm banking industry«. Journal of Social History, Fall. http://findarticles.com/p/articles/mi m2005/is 138/ai?n6234782/.

7. PHILIP REILLY 1977 Genetics, Law and Social Policy. Harvard University Press, p 199

8. DANIELS, op cit.

9. RAY KURZWEIL, TERRY GROSSMAN 2004 Fantastic Voyage: Living Long Enough to Live Forever. Rodale Books.

10. AUBREY DE GREY 2007 Ending Aging. St. Martin's Press.

11. en.wikipedia.org/wiki/List_of_countries_by_life_expectancy

12. PAUL EHRLICH 1968 The Population Bomb. Sierra Club-Ballantine Books. 